Mansohnzr, M., Richter, Ch.: Akkumulation und Translokation von $\mathrm{K}^{+}, \mathrm{Na}^{+}$und $\mathrm{Ca}^{2+}$ bei Angebot zu einzelnen Wurzelzonen von Maiskeimptlanzen. - Z. Pflanzenernähr. Bodenk. 135 : $1-15,1973$.

Monate, D. B., Barker, S. A.: Rate of nutrient uptake per unit of corn root under field con. ditions. - Agron. J. 66 : $399-402,1974$.

Newmar, E. I.: A method of estimating the total length of root in a sample. - J. appl. Ecol. $3: 139-145.1966$.

Robards, A. W., Jackson, S. M., Charkson, D. T., Sanderson, J.: The structure of barley roots in relation to the transport of ions into the stele. - Protoplasma 77 : 291-311, 1973.

Russels, E. W.: Soil Conditions and Plant Growth. 9th ed. - Longmans Gr. \& Co., London 1961.

Sachan, R. S., Sharma, R. B.: Calcium absorption as an index of root parametere of cueumber (Cucumis eativus L.) - Plant Soil 54 (in press), 1880.

\title{
BOOK REVIEW
}

Chararas, C.: Ecophysiologie des Insectes Parasites des Forets. - Édité par l'auteur, Paris 1979. 297 pp., 123 figs., 11 tables.

Constantin Chararas, Research Director of CNRS in Paris, a scientist long employed at the Institut National Agronomique, has an outstanding reputation among all entomologists study. ing bionomy, ecology and physiology of forest pests, in particular beetles of the families Scolytidae, Cerambicidae, Curculinoidae etc. He has advocated a new approach to the research of forest pest for more than 25 years, after he had demonstrated the complexity of the relationship between bark beetles and their host plants (the role of primary attractants and plant osmotic pres. sures). His experience has already been summarized in the book "Etude biologique des Scolytidae des Conifères" published in 1962. The present book Ecophysiology of Insect Forest Pests is a com. prehensive treatise based both on available literary data and his own results gathered for 30 years of his research career.

The first part of the book briefly describes the forest insects from an ecologic point of view and with emphasis on economic importance, their adaptations to various climatic conditions, and their distribution and harmful activities to the host plants. It also discusses factors, such as the primary plant attractants, which influence plant infestation.

The second part elucidates the mechanism of infestation in more detail, primarily by distinguishing between primary plant attractants and other compounds released in the forest community due to the action of insects and other interactions between the community organisms. The paragraphs on the luring activity of the terpenic compounds for xylophagous insects reflect author's experience in this field of research, which has undergone tremendous development in recent years. The significance of secondary attractants and pheromones for the spreading of several important pests is well documented.

The third part of the book deals with nourishment and digestive enzymes of insects, various types of food ingestions, and the role of taste receptors and stimuli. Importance of the composition of plant communities for the development of insect populations from the point of view of their proper nourishment is emphasized. Examination of the oxidase activity is an original contribution to this branch of research. The role of microorganisms for the digestive processes in insects is also elucidated.

The conclusive chapter is devoted to considerations on the relationships between the development of host plants and their insect pests.

In summary, the book Ecophysiology of Insect Forest Pests by C. Chararas well combines the results of modern research with the aspects of practical pest control.

V. Novák (Jílovišté-Strnady) 